\title{
Hexadecane-Degradation by Teskumurella and Stenotrophomonas Strains Iso- lated From Hydrocarbon Contaminated Soils
}

\author{
Hamid Tebyanian ${ }^{1}$, Mehdi Hassanshahian ${ }^{2, *}$, Ashraf Kariminik ${ }^{1}$ \\ ${ }^{1}$ Department of Microbiology, Science and Research Branch, Islamic Azad University, Kerman, IR Iran \\ 2 Department of Biology, Faculty of Sciences, Shahid Bahonar University of Kerman, Kerman, IR Iran \\ ${ }^{3}$ Department of Microbiology, Islamic Azad University, Kerman, IR Iran \\ ${ }^{*}$ Corresponding author: Mehdi Hassanshahian, Department of Biology, Faculty of Sciences, Shahid Bahonar University of Kerman, Kerman, IR Iran. Tel: +98-9132906971, Fax: +98-
} 3413202032, E-mail: mshahi@uk.ac.ir.

Received: November 18, 2012; Revised: January 26, 2013; Accepted: March 03, 2013

\begin{abstract}
Background: Petroleum hydrocarbons are mix compounds and divided into four groups: Saturates, Aromatics, Resins and Asphalten. Among various phases of crude-oil, the alkanes with medium length chain are favorable substrates that rapidly degraded, although short-chain alkanes are very toxic and long-chain alkanes have low solubility in water that reduce its bioavailability and make resistant to biodegradation.

Objectives: The main goal of this study is the isolation, molecular identification and degradation properties of hexadecane degrading bacteria from contaminated soils.

Materials and Methods: In this research to isolate aliphatic degrading bacteria, sampling from hydrocarbon contaminated soil with of petroleum reservoirs regions, Tehran were performed. Alkane degrading bacteria were isolated by enrichment in Bushnel-Hass medium with hexadecane as sole source of carbon and energy. The isolated strains were identified by amplification of $16 \mathrm{~S}$ rDNAgene and sequencing. Alkane hydroxylase gene (alk-B) was identified in all strains by PCR with specific primers.

Results: Among 8 strains three strains with high growth rate on hexadecane selected for further study. These three selected strains identified as Stenotrophomonas maltophilia strain M2, S. maltophilia strain Q2 and Tsukamurella tyrosinosolvens strain Q3. In comparison to the other bacteria, these bacterial strains can degrade hexadecane 2 times more; with a high emulsification activity.

Conclusions: The $2.5 \%$ concentration of hexadecane was the best concentration that supports the growth of these strains. Among these strain T. tyrosinosolvens strain Q3 was the best strain for biodegradation of hexadecane. Alk-B gene was identified in all strains.
\end{abstract}

Keywords: Biodegradation; Hexadecane; Pollution; Stenotrophomonas

\section{Background}

Petroleum hydrocarbons are important energy resources used by industry and in our everyday lives. Together petroleum is a major pollutant of the environment. The petroleum containing thousands of individual hydrocarbons and related compounds (1). Aliphatic and aromatic hydrocarbons which are the most common pollutants are the main contaminants in oil-polluted environments. Oil pollution may arise either accidentally or operationally during oil production, transportation, storing, proceeding or using at sea or on land (2-4). The traditional methods to cope with oil spills are confined to physical containment. Biological methods have the advantage over physicochemical treatment regimes in removing spills as they offer institute biodegradation of oil fraction by microorganisms $(5,6)$. Many of these remediation strategies employ microorganisms which can degrade the hydrocarbons.

Bioremediation of contaminated sites relies on either the activity of microorganisms which are presented at the site or the addition of selected microorganisms with desired catabolic features and bio-augmentation systems $(7,8)$. The rate of biodegradation depends on the oil concentration, alkanes length, biosurfactant and microorganism strains (9). It has been reported that the saturated components of crude oil are mostly the alkanes with intermediate length ( $\mathrm{C} 10$ - $\mathrm{C} 20)$ that are more readily to biodegrad (10). The rate of uptake and mineralization of various organic compounds depends on the compound concentration, high concentrations of hydrocarbon cause inhibition of biodegradation by inducing nutrient or oxygen limitation or through toxic effects of volatile hydrocarbons (11-13).

Alkane hydroxylase is a key enzyme in alkane degra- 
dation. This enzyme which carries the oxygen atom of molecular oxygen into the alkane substrate, plays an important role in crude oil bioremediation. Phylogenetic analyses have revealed that the alkane hydroxylase genes classified into three clusters. The alkane hydroxylase group (I) encoding alk-B gene catalyzes medium chain length (C6 - C12) n-alkanes. The genes classified group (II) encoding alk-M catalyzes long chain alkanes > C12 this gene is mostly contained in Acinetobacter genomes. The gene classified group (Ш) encoding alk-B is unknown for substrate specificity, alkane oxidation pathway and oxidation system (14-16).

\section{Objectives}

The main goal of this study was the isolation, molecular identification of hexadecane degrading bacteria isolated from contaminated soils.

\section{Materials and Methods}

\subsection{Sampling}

For isolation of alkane-degrading bacteria, contaminated soils were collected from 10 different sites of Tehran petroleum reservoirs regions. The samples were taken from $1-12 \mathrm{~cm}$ of the subsoil using a sterile scalpel. Collected samples were transported on ice to the laboratory for isolation (17).

\subsection{Isolation and Selection of Alkane Degrading Bacteria}

A synthetic Bushnell Hass Mineral Salts medium(BHMS) was used for isolation. BHMS medium contain (g.L-1) $\mathrm{KH} 2 \mathrm{PO} 4,1$; K2HPO4, 0.2; $\mathrm{MgSO} 4.7 \mathrm{H} 2 \mathrm{O}, 0.2 ; \mathrm{CaCl} 2,0.02$; $\mathrm{NH} 4 \mathrm{NO} 3,1$; and 2 droplet of $\mathrm{FeCl} 360 \%$. The $\mathrm{pH}$ adjusted to 7 . BHMS medium was supplemented with $1 \%(\mathrm{v} / \mathrm{v})$ hexadecane as sole carbon source of energy. Portion of soil (1 g) samples were added to $250 \mathrm{~mL}$ Erlenmeyer flasks containing $100 \mathrm{~mL}$ BHMS medium and the flask incubated for 10 days at $30^{\circ}$ and $180 \mathrm{rpm} C$ on rotary shaker (INFORS AG, Switzerland). Then $5 \mathrm{~mL}$ aliquots were remove to fresh BHMS medium. After a series of four further passages, inoculums from the flask were streaked out and different colonies phenotipically purified on BHMS agar medium. colonies grown on the plates were transferred to fresh BHMS medium with and without hexadecane to eliminate the autotrophs and agar-utilizing bacteria. The procedure was repeated and isolates only showed a pronounced growth on hexadecane were stored for further characterization (18).

\subsection{Identification of Isolates}

\subsubsection{Biochemical Characterization}

To identify and characterize the bacteria isolates, bio- chemical tests such as Gram staining, oxidation/ fermentation, production of acid from carbohydrates, hydrolysis of gelatin and citrate carried out according to the Bergey's manual of Systematic Bacteriology (19).

\subsubsection{Molecular Identification}

Analysis of $16 \mathrm{~S}$ rDNA was performed to characterize the isolated strains taxonomically. Total DNA extraction was performed using the CTAB method (20). The bacterial 16S rDNA loci were amplified using the forward domain-specific 16S primer, Bac27_F (5'-AGAGTTTGATCCTGGCTCAG-16 3) and universal reverse primer Uni_1492R (5'-TACGYTACCTTGTTACGACTT-173). The amplification reaction was performed in a total volume of $50 \mu \mathrm{L}$ containing, 1X solution Q (Qiagen, Hilden, Germany), 1X Qiagen reaction buffer, $1 \mu \mathrm{M}$ of each forward and reverse primer, $10 \mu \mathrm{M}$ dNTPs (Gobco, Invitrogen Co, Carlsbad, CA), and $2 \mathrm{U}$ of Qiagen Taq polymerase (Qiagen). Amplification for 35 cycles was performed in a thermacycler GeneAmp 5700 (PEApplied Biosystem, Foster City, CA, USA).

The temperature profile for PCR was set at $95^{\circ} \mathrm{C}$ for 5 $\min$ (1 cycle); $94^{\circ} \mathrm{C}$ for $1 \mathrm{~min}$ annealing at $55^{\circ} \mathrm{C}$ for $30 \mathrm{~s}$ and $72^{\circ} \mathrm{C}$ for $1 \mathrm{~min}$ ( 35 cycles), followed by $72^{\circ} \mathrm{C}$ for $10 \mathrm{~min}$ at the end of final cycle (21). The $16 \mathrm{~S}$ amplified (1400 bp) was sequenced with a Big Dye terminator V3.1 cycle sequencing kit on an automated capillary sequencer (model 3100 Avant Genetic 1 Analyzer, Applied Biosystems). The similarity rank from the Ribosomal Database Project RDP) (22) and FASTA Nucleotide Database Query were used to determine partial 16S rDNA sequences to estimate the degree of similarity to other $16 \mathrm{~S}$ rDNA gene sequences. Analysis and phylogenetic affiliates of sequences was performed as described previously (23).

\subsection{Growth and Hexadecane Removal Assay}

The isolates growth curves were indirectly assessed by turbidity measurement (O.D $600 \mathrm{~nm}$ ) by a UV-visible spectrophotometer (Shimadzu UV-160, Japan) in culture of bacteria in BHMS + hexadecane medium. The hexadecane removal assay was carried out by Gas chromatography analysis (18).

\subsection{Emulsification Activity and Bacterial Adher- ence to Hydrocarbons (BATH) Test}

The emulsification activity (E24) was determined by addition of hexadecane, to the same volume of cell free culture broth, vortex mixed for 2 minutes and left to stand for $24 \mathrm{~h}$. The emulsification activity was determined as the percentage of height of the emulsified layer $(\mathrm{mm}) \mathrm{di}$ vided by the total height of the liquid column ( $\mathrm{mm}$ ) (17). Bacterial adhesion assessment to hydrocarbon was carried out according to Cappello et al. 2012 (16).

\subsection{Detection of Alkane Hydroxylase Gene (alk-B) in Bacterial Isolates}


Tebyanian Het al.

Total DNA extraction of bacterial strain was performed using CTAB method (20). The purified DNA extracts were subsequently screened by PCR to detect catabolic alkB gene that encodes enzymes involve in alkane degradation pathways. Alkane hydroxylase gene was detected by alk-3F (5'-TCGAGCACATCCGCGGCCACCA-3') and alk-3R (5'-CCG TAGTGCTCGACGTAGTT-3') primers $(14,24)$. A total volume of $25 \mu \mathrm{L}$ PCR mixture containing $2 \mathrm{mM} \mathrm{MgCl} 2,10 \mathrm{X}$ strength PCR reaction buffer (200 mM Tris, $500 \mathrm{mM} \mathrm{KCl)}$, $1 \mathrm{mM}$ each dNTP, $0.15 \mathrm{mM}$ each primer and 1 Unit taq DNA polymerase was added to each tube.

Target DNA was amplified in a thermal cycler (Eppendorf AG 22331, Hamburg, Germany) with initial denaturation of the target DNA at $94^{\circ} \mathrm{C}$ for $2 \mathrm{~min}$ and then 30 repeated cycles comprised of three-step PCR amplification consisting of denaturation at $94^{\circ} \mathrm{C}$ for $1 \mathrm{~min}$, primer annealing at $54{ }^{\circ} \mathrm{C}$ for $30 \mathrm{~s}$ and primer extension at $72^{\circ} \mathrm{C}$ for $30 \mathrm{~s}$. The samples were incubated at $72^{\circ} \mathrm{C}$ for $5 \mathrm{~min}$ at the end of amplification cycles to complete the extension reaction. PCR products (330 bp) were visualized by gel electrophoresis using a horizontal $2 \%$ agarose gel (Sigma, St. Louis, MO) with 1 X TBE buffer. Gels were stained in a solution of ethidium bromide and visualized under a UVP UV transilluminator (UVP Inc., San Gabriel, CA) $(14,25)$.

\section{Results}

\subsection{Isolation and Identification of Bacteria}

Among 8 strains that isolated from enrichment cultures which established at $30^{\circ} \mathrm{C}$ for one week, three bacterial strains were selected for further studies. These strains were isolated from soil contaminated hydrocarbons. These strains were first differentiated by classical biochemical tests. Molecular identification of isolates was performed by amplification and sequencing the 16SrDNA gene sequencing and matching it to the database of known 16SrDNA sequences. The results of identification were presented in Table 1. As shown in this Table,these three strains belonged to Stenotrophomonas maltophilia and Tsukamurella tyrosinosolvens genus. The phylogenic trees of these three isolated were illustrated in Figure 1. Full sequences of three bacteria were submitted to EMBL database. Accession numbers of these strains in EMBL are: HE862282, HE862285 and HE86227 respectively.

\subsection{Growth Rate and Hexadecane Removal by Strains}

All bacterial strains were grown in the presence of $1 \%$ hexadecane for one week while shaking. After one week microbial growth, hexadecane biodegradation were analyzed by spectrometry and GC method respectively. The results of growth and degradation were presented in Table 2. As reported in this Table, $T$. tyrosinosolvens strain Q3 has demonstrated a high hexadecane biodegradation and growth rate. On the other hand, the $S$. maltophilia strain Q1 has the lowest percentage of hexadecane removal (68 percent) and growth rate among all isolates.

\subsection{The Effect of Various Hexadecane Concentra- tions on Bacterial Growth}

For determine the effect of various hexadecane concentrations on bacterial growth, selected bacterial isolates were grown at different hexadecane concentrations(1, 2.5, 4, 5.5 and 7 percent) after one week-incubation at $30^{\circ} \mathrm{C}$, the optical density was read at $600 \mathrm{~nm}$. The result of this experiment was presented in Figure 2. As shown in this Figure when the hexadecane concentrations of increased the growth rate of degradative bacteria were decrease. For example S. maltophilia strain M2 has an optical density of 1.5 at $1 \%$ hexadecane concentration $1 \%$ while this amount decreases to 0.3 in $7 \%$ hexadecane concentration. Theoptimum hexadecane concentration that leads to the high bacterial growth was $2.5 \%$.

\subsection{Adherence to Organic Phase and Emulsifica- tion Activity by Isolates}

Cell surface hydrophobicity and emulsification activity of the isolates were studied by emulsification (E24\%) and bacterial adhesion to hydrocarbon tests (BATH). The results were presented in Table 2 . These results indicated that there is a direct relationship between cell surface hydrophobicity and emulsification activity with alkane biodegradation. These results demonstrate that when a bacterial strain has high cell surface hydrophobicity it can produce more emulsifiers that enhance the alkane biodegradation.

Table 1. Closest Relatives of 16rDNA Gene Sequences of Isolated Bacteria in This Study

\begin{tabular}{llll}
\hline Isolate & Closest hit & Accession Number \\
\hline M2 & $\begin{array}{l}\text { Stenotrophomonas maltophilia strain MHF } \\
\text { ENV 20 }\end{array}$ & HE862282 & ID, \% \\
Q1 & S.maltophilia strain Ags-9 & HE862285 \\
Q3 & Tsukamurella tyrosinosolvensIFM 10623 & HE862287 & 98 \\
\hline
\end{tabular}


Figure 1. Phylogenetic Tree of 16S rDNA Sequences of the Bacterial Isolates Obtained From Petroleum Reservoirs Waste Water

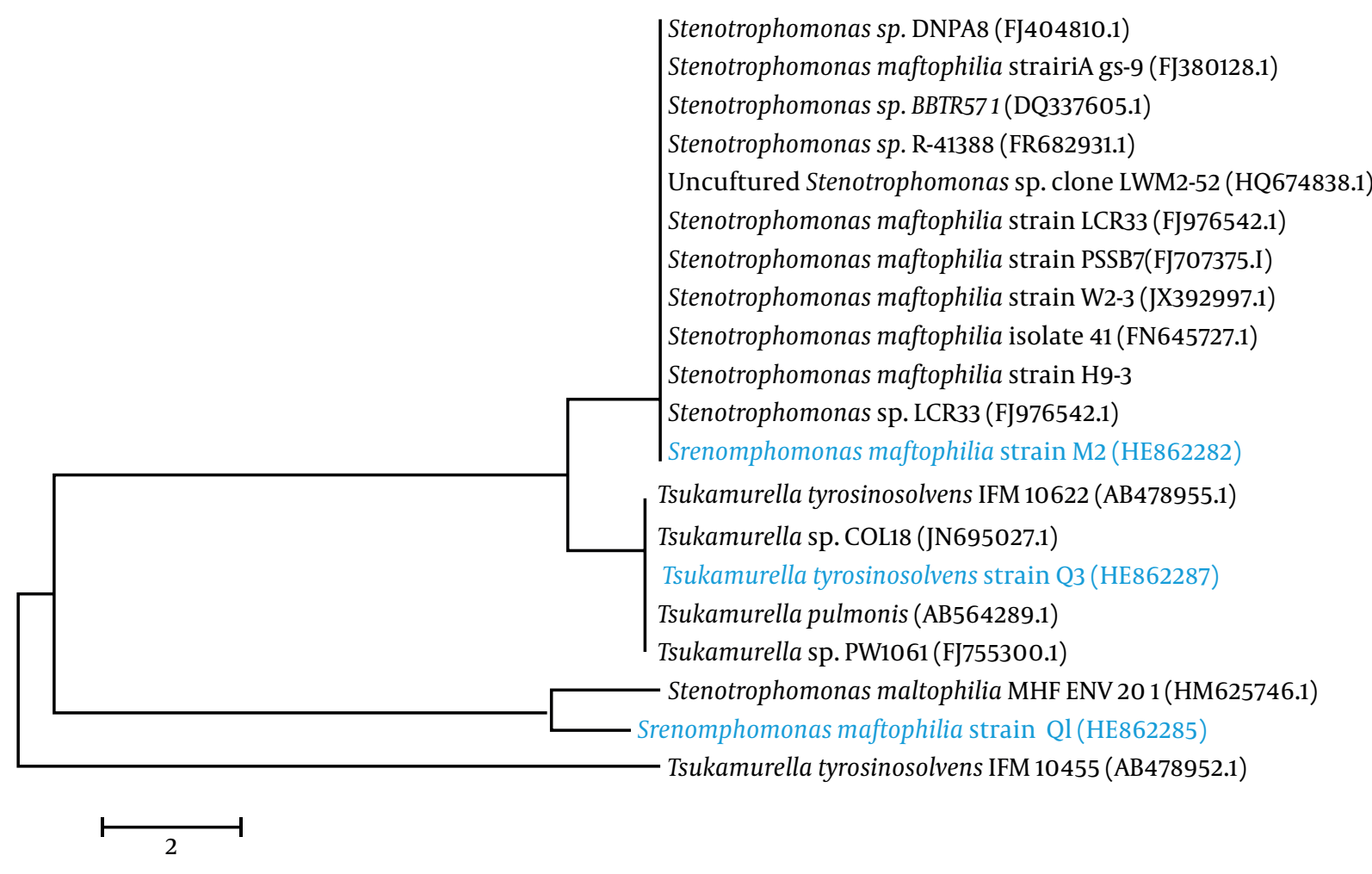

The tree was constructed using sequences of comparable $16 \mathrm{~S}$ rDNA gene sequences available in public databases. Neighbour-joining analysis using 1,000 bootstrap replicates was used to infer tree topology. The bar represents $0.1 \%$ sequence divergence. Sequenced data show the location of selected isolated strain.

Table 2. Growth Rate, Hexadecane Removal, Measurement of Emulsification Activity (E24 \%) and Cell Surface Hydrophobicity (BATH $\%)$ in Isolated Strain

\begin{tabular}{lllll}
\hline Isolate & $\begin{array}{l}\text { Growth Rate, } \\
\text { OD600nm }\end{array}$ & $\begin{array}{l}\text { Percent of hexadecane } \\
\text { Removal }\end{array}$ & $\begin{array}{l}\text { Emulsification activity, } \\
\text { E24, \% }\end{array}$ & $\begin{array}{l}\text { Cell Surface Hydropho- } \\
\text { bicity, BATH, \% }\end{array}$ \\
\hline $\begin{array}{l}\text { Stenotrophomonas } \\
\text { maltophilia strain M2 }\end{array}$ & 1.32 & 74 & 29 \\
$\begin{array}{l}\text { S.maltophilia strain } \\
\text { Q1 }\end{array}$ & 1.4 & 68 & 6.12 & \\
$\begin{array}{l}\text { Tsukamurella tyrosino- } \\
\text { solvensstrain Q3 }\end{array}$ & 1.12 & 76 & 7.14 & 24 \\
\hline
\end{tabular}

\subsection{Detection of Catabolic Gene by PCR}

The presence of catabolic gene encoding alkane hydroxylases enzymes (alkB gene) of isolated strains was determined by PCR using specific primers of this functional gene. Alk-B primers successfully amplified PCR products of expected size from all isolated strains. Figure 3 show the results of PCR analysis which verified alkane hydroxylase gene existed in all isolated strains. 
Figure 2. Effect of Various Concentrations of Hexadecane (1 - 7\%) on Bacterial Growth (as Optical Density (O.D.) at $600 \mathrm{~nm}$ ) of Three Bacterial Strains
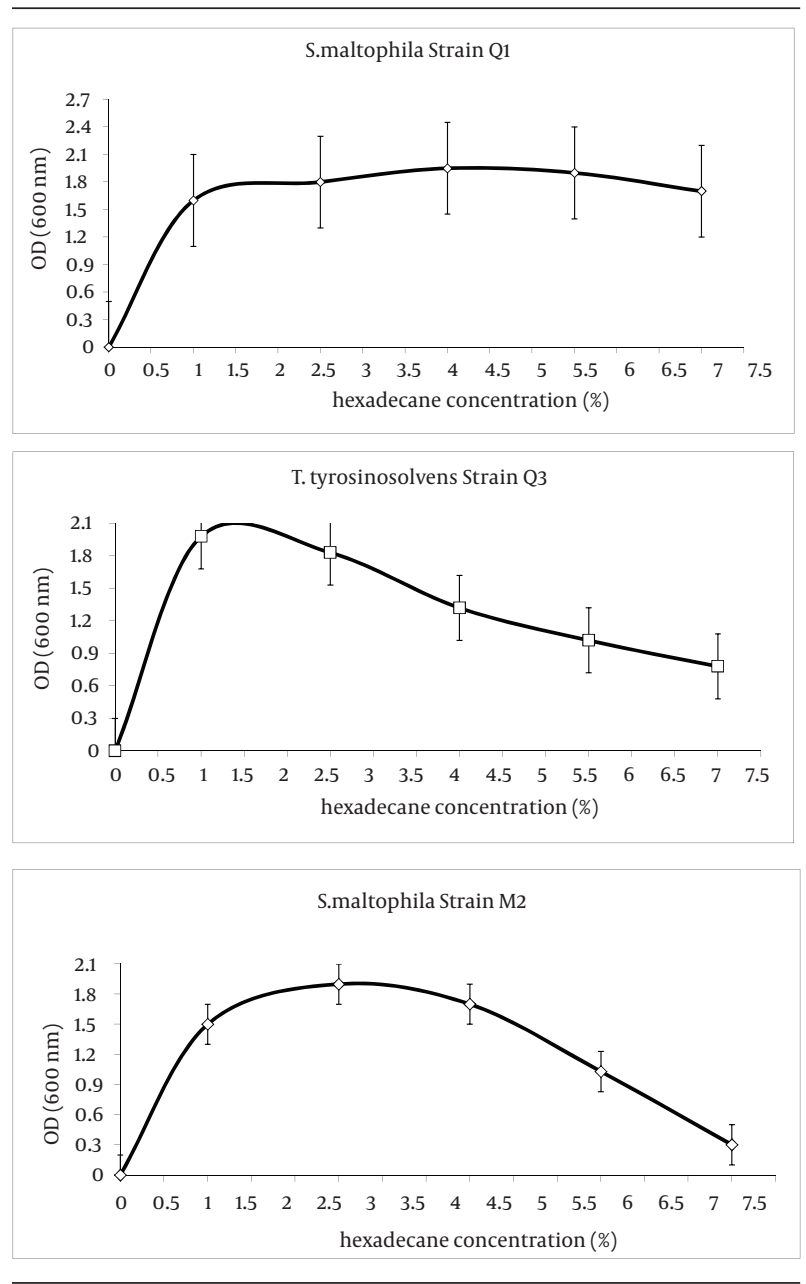

All strains were grown for 7 day at $30^{\circ} \mathrm{C}$.

\section{Discussion}

Tsukamurella spp. primarily are known as environmental saprophytes of soil, water and foam (thick stable scum on aeration vessels and sedimentation tanks) of activated sludge. Tsukamurella are represented in HPC populations in drinking-water. Tsukamurella spp. appears to be transmitted through devices such as catheters or lesions (26, 27). S. maltophilia is ubiquitous species that exists in a wide variety of environments and geographical regions, and different strains of this organism were isolated from soil as well as various nosocomial and clinical specimens. Characteristic of S. maltophilia are unusual lipopolysaccharides containing relatively large amount of the uncommon fatty acids $(28,29)$.

Sudarat et al. isolated these bacteria from soil sample of a contaminated site located in Warracknabeal (30).
Figure 3. Amplification of alk-B Gene (Alkane Hydroxylase) by PCR Analysis of DNA Extracts From Bacterial Isolates

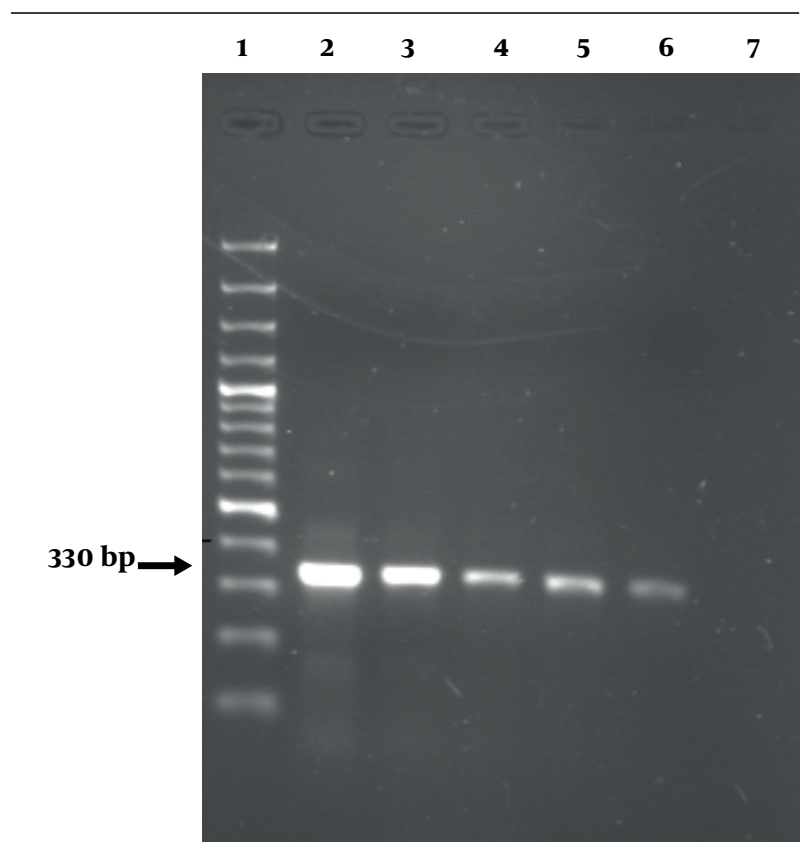

lane 1, 100 bp DNA size marker Ladder; lane 2, positive control (Acinetobacter sp.2769A); lane 3, isolate M2; lane 4, isolate Q1; lanes 5, 6 isolate Q3; lane 7, negative control.

Nicole et al. isolated these bacteria from soil of a bioremediation system at Rositz, a village in Thuringia, Germany. The contamination consisted of benzene, toluene, ethylbenzene and xylene (BTEX), polyaromatic compounds, as well as phenols (31). The key difference between our study and other reported ones is the isolation of these bacteria from petroleum reservoirs waste water and also hydrocarbon-contaminated soils in Iran (Tehran). Many reports about the isolation of aromatic hydrocarbon degrading bacteria from contaminated soil, sediment, sludge and water are available but no report on the isolation of hexadecane degrading bacteria from petroleum reservoirs waste water has been published yet.

In this study three bacterial strains with hexadecane degradation ability were isolated and identified by 16SrDNA sequence analysis. These strains belonged to the genus Stenotrophomonas, and Tsukamurella. Jurelevicius et al. has been defined the alkane degrading bacteria in soils from King George Island in Maritime Antarctic (32). They found that there is a high diversity of alkane degrading bacteria in this environment. Quatrini et al. isolated some gram positive n-alkane degraders from a hydrocarbon contaminated Mediterranean shoreline (33). Hence it is believed that bacteria must have certain mechanisms to uptake and use this hydrophobic substrate. In this study the effect of increased concentration of hexadecane from 1\% to $7 \%$ on isolated bacterial growth was studied.

We found that when the hexadecane concentration 
increased the growth rate of bacteria will decreased, however this reduction is not the identical in all strains. The optimum hexadecane concentration for growth was found $2.5 \%$. The water solubility of hexadecane is less than $0.9 \times 10^{-6} \mathrm{mg} / \mathrm{L}(18)$. Vomberg et al. isolated 45 alkane degrading bacteria belong to 37 bacterial species from soil contaminated to crude-oil in Germany. They have studied the distribution of alk-B among isolates by PCR-hybridization method and have concluded that the group (III) alkane hydroxylase is predominant among isolates (34). To date, the microorganisms carrying the alkB gene have been found in various environments, such as Alaska sediments, contaminated soil, cold ecosystems, oil-contaminated site, a shallow aquifer, bulk soil, a land treatment unit, Arctic and Antarctic soil and Sea water (35).

The gene alkB could possibly be used as a potential prediction marker to predict the of microorganism in different environments with oil degradation capability (35). Heissblanquet et al. showed that there are strong differences in the predominance of the two alk-B genotypes of freshwater and soil microcosms. However both types of alk-B gene prevalance increased in the most polluted soils (15). In this study distribution of alk-B is almost the same among 3 bacterial isolates. This result indicated that alkane hydroxylase enzyme encoded by alk-B gene is essential for hydrocarbon biodegradation.

The described results of this paper show that hexadecane degrading bacteria have more diversity and biodegradation ability of petroleum reservoirs waste water of Iran. the new isolates capability to degrade PAHs could be also investigated in further studies.

\section{Authors' Contribution}

None declared.

\section{Financial Disclosure}

None declared.

\section{Funding/Support}

This research was supported by Shahid Banonar University of Kerman.

\section{References}

1. Vinas M, Grifoll M, Sabate J, Solanas AM. Biodegradation of a crude oil by three microbial consortia of different origins and metabolic capabilities. J Ind Microbiol Biotechnol. 2002;28(5):25260.

2. Dibble AS, Cheng C, Biggar CAH. Polycyclic aromatichydrocarbon carcinogens.1990. p.109-127.

3. Collins JF, Brown JP, Alexeeff GV, Salmon AG. Potency equivalency factors for some polycyclic aromatic hydrocarbons and polycyclic aromatic hydrocarbon derivatives. Regul Toxicol Pharmacol. 1998;28(1):45-54.

4. Head IM, Jones DM, Roling WF. Marine microorganisms make a meal of oil. Nat Rev Microbiol. 2006;4(3):173-82.

5. Chaillan F, Le Fleche A, Bury E, Phantavong YH, Grimont P, Saliot $A$, et al. Identification and biodegradation potential of tropical aerobic hydrocarbon-degrading microorganisms. Res Microbiol.
2004;155(7):587-95

6. Hanson KG, Nigam A, Kapadia M, Desai AJ. Bioremediation of crude oil contamination with Acinetobacter sp. A3. Curr Microbiol.1997;35(3):191-3.

7. Cerniglia CE. Biodegradation of polycyclic aromatic hydrocarbons. Curr Opin Biotechnol.1992;21(3):351-68.

8. Shuttleworth KL, Cerniglia CE. Environmental aspects of PAH biodegradation. Appl Biochem Biotechnol. 1995;54(1-3):291-302.

9. Cappello S, Genovese M, Della Torre C, Crisari A, Hassanshahian $\mathrm{M}$, Santisi S, et al. Effect of bioemulsificant exopolysaccharide $\operatorname{EPS}(2)(0)(0)(3))$ on microbial community dynamics during assays of oil spill bioremediation: a microcosm study. Mar Pollut Bull. 2012;64(12):2820-8.

10. Roy S, Hens D, Biswas D, Biswas D, Kumar R. Survey of petroleumdegrading bacteria in coastal waters of Sunderban Biosphere Reserve. World J Microbiol Biotechnol. 2002;18(6):575-581.

11. Yuste L, Corbella ME, Turiegano MJ, Karlson U, Puyet A, Rojo F. Characterization of bacterial strains able to grow on high molecular mass residues from crude oil processing. FEMS Microbiol Ecol. 2000;32(1):69-75.

12. Chaineau CH, Rougeux G, Yepremian C, Oudot J. Effects of nutrient concentration on the biodegradation of crude oil and associated microbial populations in the soil. Soil Biol Biochem. 2005;37(8):1490-1497.

13. Emtiazi G, Hassanshahyan M, Golbang N. Development of a microtitre plate method for determination of phenol utilization, biofilm formation and respiratory activity by environmental bacterial isolates. Int Biodeter Biodegr. 2005;56(4):231-235.

14. Kohno Tetsuro, Sugimoto Yoshiro, Sei Kazunari, Mori Kazuhiro. Design of PCR primers and gene probes for general detection of alkane-degrading bacteria. Microb Environ. 2002;17(3):114-121.

15. Heiss-Blanquet S, Benoit Y, Marechaux C, Monot F. Assessing the role of alkane hydroxylase genotypes in environmental samples by competitive PCR. J Appl Microbiol. 2005;99(6):1392-403.

16. Cappello S, Santisi S, Calogero R, Hassanshahian M, Yakimov MM Characterisation of Oil-Degrading Bacteria Isolated from Bilge Water. Wat Air Soil Pollut. 2012;223(6):3219-3226.

17. Hassanshahian M, Tebyanian H, Cappello S. Isolation and characterization of two crude oil-degrading yeast strains, Yarrowia lipolytica PG-20 and PG-32, from the Persian Gulf. Mar Pollut Bull. 2012;64(7):1386-91.

18. Hassanshahian M, Emtiazi G, Cappello S. Isolation and characterization of crude-oil-degrading bacteria from the Persian Gulf and the Caspian Sea. Mar Pollut Bull. 2012;64(1):7-12.

19. Holt SG, Kriey NR, Sneath PHA, Staley JT, Williams ST. Bergy manual of determinative for bacteriology. 1998.

20. Winnepenninckx B, Backeljau T, De Wachter R. Extraction of high molecular weight DNA from molluscs. Trends Genet. 1993;9(12):407.

21. Troussellier M, Got P, Mboup M, Corbin D, Giuliano L, Cappello S, et al. Daily bacterioplankton dynamics in a sub-Saharan estuary (Senegal River, West Africa): a mesocosm study. Aquat microb ecol. 2005;40(1):13-24

22. Maidak BL, Olsen GJ, Larsen N, Overbeek R, McCaughey MJ, Woese CR. The RDP (Ribosomal Database Project). Nucleic Acids Res. 1997;25(1):109-11.

23. Yakimov Michail M, Cappello Simone, Crisafi Ermanno, Tursi Angelo, Savini Alessandra, Corselli Cesare, et al. Phylogenetic survey of metabolically active microbial communities associated with the deep-sea coral Lophelia pertusa from the Apulian plateau, Central Mediterranean Sea. Deep Sea Res. 2006;53(1):62-75.

24. Hassanshahian Mehdi, Emtiazi Giti, Kermanshahi Rouha Kasra, Cappello Simone. Comparison of oil degrading microbial communities in sediments from the Persian Gulf and Caspian Sea. Soil Sediment Contam. 2010;19(3):277-291.

25. Sei K, Sugimoto Y, Mori K, Maki H, Kohno T. Monitoring of alkanedegrading bacteria in a sea-water microcosm during crude oil degradation by polymerase chain reaction based on alkane-catabolic genes. Environ Microbiol. 2003;5(6):517-22.

26. Kattar MM, Cookson BT, Carlson LD, Stiglich SK, Schwartz MA, Nguyen TT, et al. Tsukamurella strandjordae sp. nov., a proposed new species causing sepsis. J Clin Microbiol. 2001;39(4):1467-76. 
27. Larkin JA, Lit L, Sinnott J, Wills T, Szentivanyi A. Infection of a knee prosthesis with Tsukamurella species. South Med J.1999;92(8):8312.

28. Oyiazu H, Komagata K. Grouping of Pseudomonas species on the basis of cellular fatty acid composition and the quinone system with special reference to the existence of 3-hydroxy fatty acids. $J$ Gen Appl Microbiol.1983;29(1):17-40.

29. Moss CW, Samuels SB, Liddle J, McKinney RM. Occurrence of branched-cahin hydroxy fatty acids in Pseudomonas maltophilia. J Bacteriol. 1973;114(3):1018-24.

30. Boonchan S, Britz ML, Stanley GA. Degradation and mineralization of high-molecular-weight polycyclic aromatic hydrocarbons by defined fungal-bacterial cocultures. Appl Environ Microbiol. 2000;66(3):1007-19.

31. Popp N, Schlomann M, Mau M. Bacterial diversity in the active stage of a bioremediation system for mineral oil hydrocarboncontaminated soils. Microbiology. 2006;152(Pt 11):3291-304.

32. Jurelevicius Diogo, Cotta Simone Raposo, Peixoto Raquel, Rosado Alexandre Soares, Seldin Lucy. Distribution of alkane-degrading bacterial communities in soils from King George Island, Maritime Antarctic. Eur J Soil Biol. 2012;51:37-44.

33. Quatrini P, Scaglione G, De Pasquale C, Riela S, Puglia AM. Isolation of Gram-positive n-alkane degraders from a hydrocarbon-contaminated Mediterranean shoreline. J Appl Microbiol. 2008;104(1):251-9.

34. Vomberg A, Klinner U. Distribution of alkB genes within n-alkane-degrading bacteria. JAppl Microbiol. 2000;89(2):339-48.

35. Van B, Jan B, Li Z, Duetz WA, Smits THM, Witholt B. Diversity of alkane hydroxylase systems in the environment. Oil gas sci technol. 2003;58(4):427-440. 